\title{
Relationships among mycorrhizal colonization, mineral nutrition and physiological status of Daucus carota growing on substrate from coal mine spoil heap
}

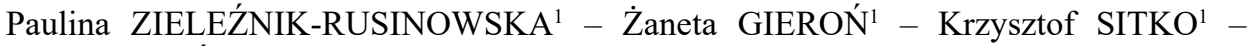
Gabriela WOŹNIAK ${ }^{2}$ - Eugeniusz MAŁKOWSKI ${ }^{1}$

1: Department of Plant Physiology, Faculty of Biology and Environmental Protection, University of Silesia in Katowice, Jagiellońska 28, 40-032 Katowice, Poland; E-mail: pzieleznik@us.edu.pl

2: Department of Botany and Nature Protection; Faculty of Biology and Environmental Protection, University of Silesia in Katowice, Jagiellońska 28, 40-032 Katowice, Poland

Keywords: plant growth, AMF, fertilization, inoculum

\section{Introduction}

As the consequences of the mining industry operation degraded lands appeared, which cover almost $1 \%$ of the world lands area. Soils at such lands are often characterized by unfavourable structure, low $\mathrm{pH}$, low availability of nutrients and low water retention capacity (Woźniak 2010). Arbuscular mycorrhizal fungi (AMF) create symbiotic associations with the roots of $80 \%$ of all terrestrial plant species. Basically the symbiosis of AMF with plants, growing under unfavourable conditions, allows better water and mineral nutrient uptake by host plants (Omirou et al. 2013). These beneficial AMF functions can be of great importance during climate change, in particular with regard to water shortages and the restoration of degraded ecosystems, including hard coal mine spoil heaps (Püschel et al. 2011). The coal spoil heaps investigated in this experiment are characteristic spots in the urban and industrial landscape of Upper Silesia, Poland. The relationships between mycorrhizal colonization, mineral nutrition and the physiological status of Daucus carota (carrot) growing on the soil from a hard coal mine spoil heap was examined. The aim of the study was to gather information in order to better design strategies for the reclamation of post-mining sites using the combination of inoculation with AMF and proper fertilization.

\section{Materials and methods}

The soil substrate was collected from a post-coal mine spoil heap located in GliwiceSośnica (Soutern Poland). The experimental design included different combinations of AMF inocula and two doses of complete mineral fertilization (low and high) to assess the impact on growth and physiological status of carrot, which seeds were collected on the spoil heap under study. Two different types of inoculation were tested: a commercial inoculum and a mix of strains indigenous to the heap (including Funneliformis mosseae USK_A3 and Rhizoglomus silesianum USK_A5). The treatment without inoculation and fertilization was used as a control. Experiments were conducted in controlled conditions in a greenhouse. After 90 days of growth the photosynthetic and transpiration rate, the content of pigments (chlorophylls and anthocyanins) and malondialdehyd (MDA) as well as biomass were measured. 


\section{Results and discussion}

We showed that without mineral fertilization and with low dose of fertilization both types of inoculum did not affect the carrot growth. On the other hand, under high fertilization, we observed that inoculation improved significantly the growth of carrot. Furthermore, the native inoculum was found more effective than the commercial one. These results are partially in contrast with the paradigmatic view that high fertilization should inhibit the growth and root colonization by AMF. However, our results are in agreement with data obtained by Gucwa-Przepióra et al. (2007), who found that high dose of phosphate fertilizer applied to soil contaminated with heavy metals considerably increased plant growth and root colonization by AMF in situ. The growth effect was positively correlated with the stimulation of photosynthetic rate and the highest photosynthetic rate was measured in plants treated with a high dose of fertilizer and native inoculum. Moreover, the native AMF significantly stimulated the transpiration under both low and high fertilization, when compared to the commercial inoculum. Chlorophyll biosynthesis was stimulated primarily by fertilization, with the highest chlorophyll index when in combination with the native inoculum. An opposite trend was observed for the anthocyanin index. Moreover, native inoculum, especially under low fertilization treatment, decreased the anthocyanin content more than other treatments. Fertilization diminished the concentration of MDA irrespective of its dose and type of inoculum.

\section{Conclusions}

The best growth of Daucus carota on post-coal mine spoil heap substrate was found when a high dose of mineral fertilization was combined with indigenous AM fungi inoculation.

\section{Acknowledgement}

The study was part of the InfoRevita project TANGO ID:268600 financed by NCBiR

\section{References}

Gucwa-Przepióra, E., Małkowski, E., Sas-Nowosielska, A., Kucharski, R., Krzyżak, J., Kita, A., Römkens P.F.A.M. (2007): Effect of chemophytostabilization practices on arbuscular mycorrhiza colonization of Deschampsia cespitosa ecotype Waryński at different soil depths. Environ Pollut 150: 338-346. DOI: https:// doi.org/10.1016/j.envpol.2007.01.024

Omirou, M., Ioannides, I.M., Ehaliotis, C. (2013): Mycorrhizal inoculation affects arbuscular mycorrhizal diversity in watermelon roots, but leads to improved colonization and plant response under water stress only. Appl. Soil Ecol. 63: 112-119. DOI: https://doi.org/10.1016/j.apsoil.2012.09.013

Püschel, D., Rydlová, J., Sudová, R., Gryndler, M., Vosátka, M. (2011): The potential of mycorrhizal inoculation and organic amendment to increase yields of Galega orientalis and Helianthus tuberosus in a spoil bank substrate. J. Plant Nutr. Soil Sci. 174: 664-672. DOI: https://doi.org/10.1002/jpln.201000307

Woźniak, G. (2010): Diversity of vegetation on coal-mine heaps of the Upper Silesia (Poland): Zróżnicowanie roślinności na zwałach pogórniczych Górnego Śląska. Szafer Institute of Botany, Polish Academy of Sciences, Kraków, Poland. 